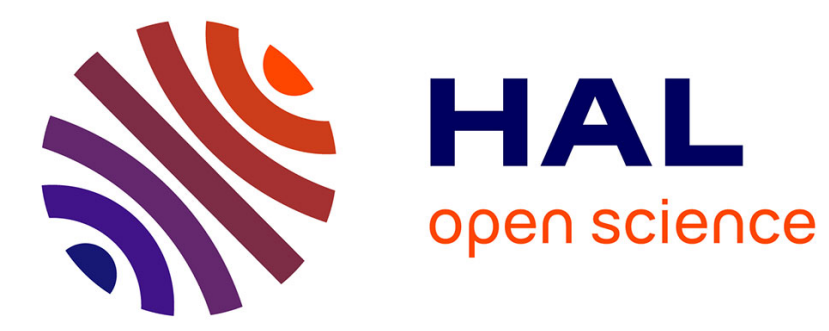

\title{
Nickel bioaccumulation in bivalves from the New Caledonia lagoon: Seawater and food exposure
}

\author{
Laëtitia Hédouin, O. Pringault, Marc Metian, Paco Bustamante, Michel
}

Warnau

\section{- To cite this version:}

Laëtitia Hédouin, O. Pringault, Marc Metian, Paco Bustamante, Michel Warnau. Nickel bioaccumulation in bivalves from the New Caledonia lagoon: Seawater and food exposure. Chemosphere, 2007, 66 (8), pp.1449-1457. 10.1016/j.chemosphere.2006.09.015 . hal-00470288

\section{HAL Id: hal-00470288 \\ https://hal.science/hal-00470288}

Submitted on 5 Apr 2010

HAL is a multi-disciplinary open access archive for the deposit and dissemination of scientific research documents, whether they are published or not. The documents may come from teaching and research institutions in France or abroad, or from public or private research centers.
L'archive ouverte pluridisciplinaire HAL, est destinée au dépôt et à la diffusion de documents scientifiques de niveau recherche, publiés ou non, émanant des établissements d'enseignement et de recherche français ou étrangers, des laboratoires publics ou privés. 


\section{lagoon: Seawater and food exposure}

$5{ }^{1}$ International Atomic Energy Agency - Marine Environment Laboratory, 4 Quai Antoine Ier,

6 MC-98000 Principality of Monaco

$7 \quad 2$ Institut de Recherche pour le Développement, BP A5, 98848 Nouméa, New-Caledonia

$8{ }^{3}$ Centre de Recherche sur les Ecosystèmes Littoraux Anthropisés, UMR-6217

9 CNRS/IFREMER/Université de La Rochelle, 22, Avenue M. Crépeau, F-17042 La

10 Rochelle, France

11

12

*Corresponding author: Laetitia Hédouin

13

14

15

16

17

18

19

20
IAEA - Marine Environment Laboratory

4 Quai Antoine 1er

MC-98000 Monaco

Principality of Monaco

E-mail: hedouinlaetitia@yahoo.fr

Phone: +3779797 7258

Fax: $\quad+37797977276$ 
The New Caledonian lagoon is submitted to intense heavy metal input from land-based Ni mining. Therefore, the use of sentinel species is strongly recommended in order to develop and implement coastal zone management programmes of the metal contamination. The tropical oysters Isognomon isognomon and Malleus regula and the clam Gafrarium tumidum were previously proposed as such possible sentinel organisms and were thus investigated in this context. The three species were exposed to $\mathrm{Ni}$ via seawater or food using radiotracer techniques. Results indicate that uptake and retention efficiencies of $\mathrm{Ni}$ are independent of the dissolved Ni concentrations in the surrounding seawater. Hence, for the three species, body concentrations of $\mathrm{Ni}$ taken up from the dissolved phase are directly proportional to the ambient dissolved concentrations. Biokinetic patterns indicated that the major part of Ni was rapidly lost from bivalves during the first days of depuration, whereas 7 to $47 \%$ of ${ }^{63} \mathrm{Ni}$ were retained in tissues with a biological half-life not significantly different from infinity. Finally, feeding experiments showed that $\mathrm{Ni}$ ingested with food (phytoplankton) was assimilated more efficiently in clams (assimilation efficiency, $\mathrm{AE}=61 \%$ ) than in oysters $(\mathrm{AE}=17 \%$ ), and was strongly retained $\left(T_{b^{1 / 2}} \geq 35 d\right)$ in the tissues of both bivalves. It is concluded that the investigated species examined are efficient bioaccumulators of $\mathrm{Ni}$ from both the surrounding seawater and the food, and that they would be useful bioindicators for monitoring the status of Ni contamination in tropical coastal waters.

Keywords: Metal, Molluscs, Mining Activities, Bioindicator, Radiotracer 


\section{Introduction}

Besides being the second largest lagoon in the world with a high rate of biodiversity species and endemism, the New Caledonian lagoon is also subject to enhanced contamination pressure (Labrosse et al., 2000; Bouchet et al., 2002). Indeed, the largest resources of Ni as laterites in the world (20-25\%) are present in New Caledonia, currently the third largest producer of Ni in the world (Dalvi et al., 2004).

Laterite deposits are made up of two ore sources available for mining extraction: limonite and saprolite ores which contain 1 to $1.6 \%$ and 1.6 to $3 \%$ of Ni, respectively. Due to their higher $\mathrm{Ni}$ content, saprolite ores have been traditionally exploited using pyrometallurgical process since the end of the nineteenth century. Future trend is expected to use limonite ores as well. INCO, one of the world largest Ni producers is currently developing a hydrometallurgical extraction plant in Goro (southern territory of New Caledonia) which will be based on acid extraction (viz. lixiviation).

Mining activities and their development represent an issue of concern in New Caledonia, due to a series of factors including increasing deforestation, soil erosion, extinction of endemic species and increasing Ni contamination in local waters (Bird et al., 1984; Labrosse et al., 2000). However, to the best of our knowledge, information available on impacts of open-cast mining in the marine coastal ecosystems of New Caledonia is extremely scarce (Monniot et al., 1994; Breau, 2003; Hédouin et al., 2006).

Among the common approaches used to survey environmental contamination, the use of bioindicator species has proven to be a valuable and informative tool (Goldberg et al., 1983; Phillips, 1990). In order to develop a biomonitoring programme to assess the levels of metal contamination in New Caledonia lagoon, studies have been recently undertaken to screen local species for their bioindicative potential (Breau, 2003). In particular, both laboratory and 
field studies have shown that two oysters (Isognomon isognomon and Malleus regula) and one clam (Gafrarium tumidum) efficiently concentrate several elements (Ag, As, $\mathrm{Cd}, \mathrm{Co}, \mathrm{Cr}$, $\mathrm{Cu}, \mathrm{Mn}, \mathrm{Ni}$ and $\mathrm{Zn}$ ) and that they are able to discriminate among locations subject to contrasting levels of contamination (Hédouin, 2006). However, current information on $\mathrm{Ni}$ bioaccumulation is rather limited; in particular no data are available on the tissue distribution or bioaccumulation kinetics of $\mathrm{Ni}$ taken up through the dissolved and dietary pathways in these organisms. Therefore, the objective of the present study was to determine the bioaccumulation capacity of $\mathrm{Ni}$ from food and seawater in these three bivalves in order to assess their potential as bioindicators of environmental $\mathrm{Ni}$ contamination.

\section{Materials \& methods}

\subsection{Collection and acclimation}

In October 2003, the clams Gafrarium tumidum were collected by sea-shore fishing in Dumbéa Bay $\left(22^{\circ} 11^{\prime} 25 \mathrm{~S}, 166^{\circ} 24^{\prime} 38 \mathrm{E}\right)$ and the two oysters Isognomon isognomon and Malleus regula were collected by SCUBA diving in Maa Bay $\left(22^{\circ} 12^{\prime} 29, \mathrm{~S}_{166^{\circ}} 19^{\prime} 42 \mathrm{E}\right)$, in a similar environment, New Caledonia. Although both oysters are abundant in Maa Bay (Breau, 2003), their quite close external appearance makes them difficult to differentiate one from the other during SCUBA sampling; hence a larger number of $M$. regula were collected compared

to I. isognomon. However, as the oysters I. isognomon and M. regula are extremely close species from their ecophysiological characteristics too (Yonge, 1968), M. regula was used as a representative oyster in the seawater exposure experiments, whereas I. isognomon was used in the food exposure experiments. To ensure comparability of both oysters, some $I$. isognomon individuals were also included in the seawater experiments.

Oysters and clams were acclimated to laboratory conditions for one week prior to the experiments (close circuit aquarium; daily water renewal, salinity: $35 \pm 1$ p.s.u.; temperature $=$ 
$25 \pm 1^{\circ} \mathrm{C} ; \mathrm{pH}=8.0 \pm 0.1$; light/dark cycle: $12 \mathrm{hrs} / 12 \mathrm{hrs}$ ). Since body size is known to affect metal concentrations in organisms (Boyden, 1977), only individuals with shell width $\geq 35 \mathrm{~mm}$ for G. tumidum and shell length $\geq 70 \mathrm{~mm}$ for I. isognomon and M. regula were used in the experiments (Metian, 2003; Hédouin et al., 2006).

\subsection{Testing influence of dissolved Ni concentrations}

Five groups of 51 G. tumidum clams (shell width from 35 to $44 \mathrm{~mm}$; wet wt from 15 to $38 \mathrm{~g}$ ), five groups of $51 \mathrm{M}$. regula oysters (shell length from 85 to $135 \mathrm{~mm}$; wet wt from 14 to $48 \mathrm{~g}$ ) and five groups of 5 I. isognomon oysters (shell length from 80 to $140 \mathrm{~mm}$; wet wt from 13 to $45 \mathrm{~g}$ ) were placed in 5 aquaria of 501 of natural seawater (close circuit aquarium; salinity: 35 \pm 1 p.s.u.; temperature $=25 \pm 1^{\circ} \mathrm{C} ; \mathrm{pH}=8.0 \pm 0.1$; light/dark cycle: $12 \mathrm{hrs} / 12 \mathrm{hrs}$ ). Seawater salinity, temperature and $\mathrm{pH}$ were checked twice daily during the experiment.

Each group of bivalves was exposed for $14 \mathrm{~d}$ to five added $\mathrm{Ni}$ concentrations $(0,15,75,350$ and 1,400 ng Ni $\mathrm{r}^{-1}$ ). The concentrations of $\mathrm{Ni}$ were adjusted using increasing amounts of $\mathrm{Ni}\left(\mathrm{NO}_{3}\right)_{2}$ (Merck, synthesis quality) and a fixed activity $\left(1 \mathrm{kBq} \mathrm{l}^{-1}\right)$ of the corresponding radiotracer ${ }^{63} \mathrm{Ni}$, as high specific activity ${ }^{63} \mathrm{NiCl}_{2}\left(\mathrm{~T}_{1 / 2}=100 \mathrm{yrs}\right)$ purchased from Amersham, UK. This radiotracer spike corresponded to $4.2 \mathrm{ng}$ stable $\mathrm{Ni}^{-1}$, a concentration at least 1 order of magnitude lower than the background concentrations of $\mathrm{Ni}$ in open seas (Bruland, 1983). No $\mathrm{pH}$ variation was detectable after stable metal and radiotracer addition. Seawater and spikes were renewed daily for $5 \mathrm{~d}$, then every second day in order to keep exposure concentration and radioactivity levels as constant as possible. Activity of the radiotracer in seawater was checked daily, and before and after each seawater renewal, to determine its time-integrated activity (Warnau et al., 1996). For the entire experimental time course, the time-integrated ${ }^{63} \mathrm{Ni}$ activity in seawater was $0.81 \mathrm{kBq}^{-1}$.

During the exposure period, 3 individuals of G. tumidum and M. regula were collected after different time intervals; soft tissues were separated from shells and prepared for whole soft 
116 tissues radioanalysis (see section II.4.). The last day $\left(\mathrm{t}_{14 \mathrm{~d}}\right), 5$ individuals of $G$. tumidum,

117 M. regula and I. isognomon were dissected to determine body distribution of incorporated

$118{ }^{63} \mathrm{Ni}$. Dissected body compartments were digestive gland, gills, mantle, foot, muscle and

119 remaining soft tissues for clams and visceral mass + mantle, gills and muscle for oysters.

120 At the end of the 14-d exposure, the remaining organisms were placed in $60 \times 60 \times 60 \mathrm{~cm}$ 121 plastic cages for $32 \mathrm{~d}$ in Sainte-Marie Bay, Nouméa, New Caledonia at $7 \mathrm{~m}$ depth. The 122 selected area $\left(22^{\circ} 18^{\prime} 55 \mathrm{~S}, 166^{\circ} 27^{\prime} 98 \mathrm{E}\right)$ is characterized by relatively low $\mathrm{Ni}$ levels 123 (Hédouin, 2006). At different time intervals of the depuration period, for each concentration 124 tested, 3 G. tumidum and 3 M. regula individuals were collected, the soft tissues dissected 125 from shells and then prepared for soft parts radioanalysis. The last day $\left(\mathrm{t}_{32 \mathrm{~d}}\right), 5$ G. tumidum 126 were dissected into different body compartments to determine the tissue distribution of the 127 remaining ${ }^{63} \mathrm{Ni}$.

\subsection{Exposure via the food}

129 Cells of the Prymnesiophyceae Isochrysis galbana $\left(10^{3}\right.$ cell $\left.\mathrm{ml}^{-1}\right)$ which originated from 130 axenic stock cultures were resuspended in an Erlenmeyer flask containing 51 sterile-filtered $131(0.22 \mu \mathrm{m})$ seawater enriched with $\mathrm{f} / 2$ nutrients without EDTA and Si. Seawater was spiked 132 with ${ }^{63} \mathrm{Ni}\left(5 \mathrm{kBq} \mathrm{l}^{-1}\right)$, and the cells were then incubated at $25^{\circ} \mathrm{C}$ (light/dark cycle: $12 \mathrm{hrs} / 12$ $133 \mathrm{hrs}$ ). After $6 \mathrm{~d}$ of incubation, cell density increased from $10^{3}$ to $1.310^{6} \mathrm{cell} \mathrm{ml}^{-1}$. A sample of $13410 \mathrm{ml}$ of the culture was then gently filtered $\left(47 \mathrm{~mm}\right.$ diameter Polycarbonate Nuclepore ${ }^{\circledR}$ 135 filter, $1 \mu \mathrm{m}$ mesh size) and the radioactivity associated with I. galbana cells was mesured 136 before and after the filtration $\left(3.410^{-6} \mathrm{~Bq}^{63} \mathrm{Ni}\right.$ cell $\left.{ }^{-1}\right)$.

137 Bivalves ( $\mathrm{n}=196$ G. tumidum, $\mathrm{n}=196$ I. isognomon) were placed in a 3001 aquarium (close 138 circuit aquarium constantly aerated; salinity: $35 \pm 1$ p.s.u.; temperature $=25 \pm 1{ }^{\circ} \mathrm{C} ; \mathrm{pH}=8.0$ $139 \pm 0.1)$ and fed the radiolabelled I. galbana for $2 \mathrm{hrs}\left(10^{4} \mathrm{cell} \mathrm{ml}^{-1}\right)$. Immediately after feeding, 
14014 individuals per species were collected and dissected to separate whole soft parts from

141 shells.

142 The remaining bivalves were then placed in Sainte-Marie Bay in plastic cages as previously

143 described. At different time intervals, 14 individuals of each species were collected in order to

144 follow loss kinetics of ${ }^{63} \mathrm{Ni}$ ingested with food. At 12 and $46 \mathrm{~d}$, collected individuals were

145 dissected to determine the distribution of ${ }^{63} \mathrm{Ni}$ content among the different body 146 compartments.

\subsection{Sample preparation and Radioanalyses}

148 Seawater samples (2 ml) were directly transferred to 20-ml glass scintillation vials (Packard)

149 and mixed with $10 \mathrm{ml}$ of scintillation liquid (Ultima Gold ${ }^{\circledR}$, Packard). The separated body 150 compartments and whole soft parts of bivalves were weighed (wet wt), dried at $60^{\circ} \mathrm{C}$ until 151 constant weight, and weighed again (dry wt). Clam and oyster tissues were then digested for 152 one week $\left(50^{\circ} \mathrm{C}\right)$ with $1 \mathrm{ml}$ Soluene ${ }^{\circledR}$ (Packard) per $100 \mathrm{mg}$ dry wt tissues, and then mixed 153 with scintillation liquid (Hionic Fluor ${ }^{\circledR}$, Packard) in proportion 1: 5 (v: v). Bivalve shells were 154 leached in three successive baths $(20 \mathrm{~min})$ of $2 \mathrm{~N} \mathrm{HCl}$ in order to recover all the ${ }^{63} \mathrm{Ni}$ adsorbed 155 onto shells. Samples of $1 \mathrm{ml}$ were transferred to $20-\mathrm{ml}$ glass scintillation vials and mixed in 156 proportion 1:10 (v: v) with scintillation liquid (Ultima Gold $\left.{ }^{\circledR}\right)$.

157 The radioactivity of ${ }^{63} \mathrm{Ni}$ was counted using a 1600 TR Packard Liquid Scintillation Analyzer.

158 Counting time was adapted to obtain a propagated counting error less than $5 \%$ (maximal 159 counting duration 2 hrs). The radioactivity was determined by comparison with standards of 160 known activities and measurements were corrected for counting efficiency, physical 161 radioactive decay and quenching effects. 


\subsection{Data analyses}

163 Uptake of ${ }^{63} \mathrm{Ni}$ was expressed in terms of concentration factor (CF: ratio between activity of

164 the radiotracer in the whole soft parts or in a body compartment $-\mathrm{Bq} \mathrm{g}^{-1}$ dry wt- and time-

165 integrated activity of the radiotracer in seawater $-\mathrm{Bq} \mathrm{ml}^{-1}$-). Radiotracer uptake kinetics were

166 described using either a simple linear regression model (eq. 1) or, if the observed kinetics

167 tended to reach a steady state, a saturation exponential model (eq. 2):

$168 \quad \mathrm{CF}_{\mathrm{t}}=\mathrm{k}_{\mathrm{u}} \mathrm{t}$ (eq. 1)

$169 \mathrm{CF}_{\mathrm{t}}=\mathrm{CF}_{\mathrm{ss}}\left(1-\mathrm{e}^{-\mathrm{k}_{\mathrm{e}} \mathrm{t}}\right)($ eq. 2$)$

170 where $\mathrm{CF}_{\mathrm{t}}$ and $\mathrm{CF}_{\mathrm{ss}}$ are the concentration factors at time $\mathrm{t}(\mathrm{d})$ and at steady state $\left(\mathrm{ml} \mathrm{g}^{-1}\right)$,

$171\left(\mathrm{CF}_{\mathrm{ss}}=\frac{\mathrm{k}_{\mathrm{u}}}{\mathrm{k}_{\mathrm{e}}}\right) ; \mathrm{k}_{\mathrm{u}}$ is the uptake rate constant $\left(\mathrm{ml} \mathrm{g}^{-1} \mathrm{~d}^{-1}\right)$ and $\mathrm{k}_{\mathrm{e}}$ is the depuration rate constant

$172\left(\mathrm{~d}^{-1}\right)$ (Whicker and Schultz, 1982; Thomann et al., 1995). Linearity of the uptake kinetics was

173 tested by a linearity test for regression with replication (Zar, 1996).

174 Loss of ${ }^{63} \mathrm{Ni}$ was expressed in term of percentage of remaining radioactivity (radioactivity at

175 time $\mathrm{t}$ divided by initial radioactivity measured in the organisms immediately after the feeding

176 period). The loss kinetics were best fitted by either a single-component exponential equation

177 (eq. 3), a single-component exponential equation with an additional constant term (eq. 4), or a

178 double-component exponential equation (eq. 5):

$179 \quad \mathrm{~A}_{\mathrm{t}}=\mathrm{A}_{0} \mathrm{k}_{\mathrm{e}} \mathrm{t}($ eq. 3)

$180 \quad \mathrm{~A}_{\mathrm{t}}=\mathrm{A}_{0 \mathrm{~s}} \mathrm{e}^{-\mathrm{k}_{\mathrm{es}} \mathrm{t}}+\mathrm{A}_{01}$ (eq. 4)

$181 \quad A_{t}=A_{0 s} e^{-k_{e s} t}+A_{01} e^{-k_{e l} t}($ eq. 5)

182 where $A_{t}$ and $A_{0}$ are the remaining activities (\%) at time $t(d)$ and 0 , respectively; $\mathrm{k}_{\mathrm{e}}$ is the 183 depuration rate constant $\left(\mathrm{d}^{-1}\right)$; ' $\mathrm{s}$ ' and ' $\mathrm{l}$ ' are the subscripts for the 'short-lived' and 'long-

184 lived' components. For each exponential component (s and 1), a biological half-life can be 185 calculated $\left(\mathrm{T}_{\mathrm{b}^{1 / 2 s}}\right.$ and $\left.\mathrm{T}_{\mathrm{b}^{1 / 2} / 2}\right)$ from the corresponding depuration rate constant $\left(\mathrm{k}_{\mathrm{es}}\right.$ and $\mathrm{k}_{\mathrm{el}}$, 
186 respectively) according to the relation $\mathrm{T}_{\mathrm{b}^{1} / 2}=\frac{\ln 2}{\mathrm{k}_{\mathrm{e}}}$. The additional constant term of equation 4

187 represents a fraction $\mathrm{A}_{01}$ of the radiotracer incorporated that is sequestrated in the organism 188 tissues.

189 Regarding feeding experiments, the 'long-lived' exponential term describes the proportion of 190 the radiotracer ingested with food that is actually absorbed by the organism and slowly 191 eliminated. The corresponding $\mathrm{A}_{01}$ represents the assimilation efficiency (AE) of the 192 considered element.

193 Model constants and their statistics were estimated by iterative adjustment of the model and

194 Hessian matrix computation, respectively using the nonlinear curve-fitting routines in the 195 Statistica 5.2.1 software. Best fitting models were selected according to the highest 196 determination coefficient and examination of residuals.

197 In order to assess possible effect of dissolved $\mathrm{Ni}$ concentration on bioconcentration behaviour, 198 estimated kinetic parameters $\left(\mathrm{k}_{\mathrm{u}}, \mathrm{CF}_{\mathrm{ss}}, \mathrm{A}_{01}, \mathrm{k}_{\mathrm{el}}\right)$ were plotted against the concentration of total 199 Ni (stable + stable equivalent of added radiotracer) in seawater and were fitted using simple 200 linear regression. Statistical comparisons were also performed using 1-way ANOVA followed 201 by the multiple comparison test of Tukey (Zar, 1996).

202 The level of significance for statistical analyses was always set at $\alpha=0.05$.

203 3. Results

\subsection{Seawater exposure to different Ni concentrations}

205 Uptake of ${ }^{63} \mathrm{Ni}$ in whole soft parts of the clam G. tumidum and the oyster M. regula displayed 206 linear kinetics at all of the five exposure concentrations tested $\left(\mathrm{p}<0.0001, \mathrm{R}^{2}: 0.79-0.92\right.$ for 207 G. tumidum and 0.63-0.72 for M. regula) (Table 1 and Fig. 1-A1). Statistical analysis 
208 indicated that uptake rate constants $\mathrm{k}_{\mathrm{u}}$ in both clams and oysters did not differ significantly 209 over the range of concentrations tested.

210 After $14 \mathrm{~d}$ of exposure, the concentration factors $\left(\mathrm{CF}_{14 \mathrm{~d}}\right)$ of ${ }^{63} \mathrm{Ni}$ were calculated in the 211 different body compartments of the clam as well as in both oysters (M. regula and $I$. 212 isognomon) (Table 2). In all three bivalves, whole soft part $\mathrm{CF}_{14 \mathrm{~d}}$ was one to three orders of 213 magnitude higher than those calculated for shells. Table 2 indicates that ${ }^{63} \mathrm{Ni}$ was concentrated 214 selectively by the different body compartments in each species, according to the following 215 order:

216 - G. tumidum: digestive gland $\left(\mathrm{CF}_{14 \mathrm{~d}}\right.$ up to 620$)>$ gills $>$ remaining tissues $>$ mantle $>$ muscle $217 \approx$ foot,

218 - I. isognomon: gills $\left(\mathrm{CF}_{14 \mathrm{~d}}\right.$ up to 660$)>$ visceral mass + mantle $>$ muscle,

$219-$ M. regula: visceral mass + mantle $\left(\mathrm{CF}_{14 \mathrm{~d}}\right.$ up to 270$)>$ gills $\approx$ muscle.

220 In general, no significant difference was found among $\mathrm{CF}_{14 \mathrm{~d}}$ in whole soft parts as well as in 221 body compartments over the range of concentrations tested. The only exception was 222 I. isognomon, for which the $\mathrm{CF}_{14 \mathrm{~d}}$ calculated in whole soft parts, gills and visceral mass + 223 mantle for the highest Ni concentration $\left(1,400 \mathrm{ng}\right.$ added $\left.\mathrm{Ni} \mathrm{l}^{-1}\right)$ were found to be significantly 224 different from the ones calculated for $75 \mathrm{ng}$ added $\mathrm{Ni}^{-1}$ ( $\mathrm{p}_{\text {Tukey }}=0.026,0.046$ and 0.043 , 225 respectively).

226 Comparisons of $\mathrm{CF}_{14 \mathrm{~d}}$ in the whole soft parts and body compartments between I. isognomon 227 and $M$. regula indicated that no significant difference was found for the whole soft parts, 228 except for $15 \mathrm{ng}$ added $\mathrm{Ni}^{-1}$, for which I. isognomon displayed a significantly higher CF than 229 M. regula $\left(\mathrm{p}_{\text {Tukey }}=0.002\right)$. Regarding body compartments, no significant difference was found 230 for visceral mass + mantle and muscle between the two species ( $\mathrm{p}_{\text {Tukey }}$ always $>0.05$ ), 231 whereas $\mathrm{CF}_{14 \mathrm{~d}}$ in gills of I. isognomon were significantly higher than those of M. regula at 232 each concentration tested ( $\mathrm{p}_{\text {Tukey }}$ always $\leq 0.04$ ). 
233 In terms of body load distribution, ${ }^{63} \mathrm{Ni}$ was mainly found in the digestive gland for clams (36 234 to $47 \%$ of total body load; Fig. 2-A1) and in the visceral mass + mantle for both oysters (67 235 to $82 \%$ of total body load; Fig. 2-A2). The body distribution of ${ }^{63} \mathrm{Ni}$ was similar over the 236 entire range of concentrations tested.

237 At the end of the exposure time, non-contaminating conditions were restored and loss kinetics 238 of ${ }^{63} \mathrm{Ni}$ were followed in the field for $32 \mathrm{~d}$. Loss kinetics from whole soft parts were best 239 described by a double exponential model in G. tumidum, whereas a single-component 240 exponential equation with an additional constant term best fitted the loss kinetics in M. regula 241 (Table 1 and Fig. 1-A2).

242 A relatively small fraction $(<14 \%)$ of ${ }^{63} \mathrm{Ni}$ was lost from the long-lived component in $M$. 243 regula, whereas this component contained 27 to $47 \%$ of ${ }^{63} \mathrm{Ni}$ in G. tumidum (Table 1). 244 However, in both species, the estimated loss rate constants of the long-lived components $\left(\mathrm{k}_{\mathrm{el}}\right)$ 245 were not significantly different from $0(\mathrm{p}>0.05)$, and therefore the derived biological half246 lives of ${ }^{63} \mathrm{Ni}$ in clams and oysters were virtually infinite at all the exposure concentrations 247 tested. In addition, in both species, linear regressions established between estimated $\mathrm{A}_{01}$ and 248 exposure concentrations displayed slopes not significantly different from 0 for both clams (p $249=0.71)$ and oysters $(\mathrm{p}=0.34)$, indicating that ${ }^{63} \mathrm{Ni}$ was assimilated similarly (in relative \%) in 250 each species regardless of the exposure concentration.

251 The distribution of ${ }^{63} \mathrm{Ni}$ among the body compartments of the clam was determined at the end 252 of the depuration period (Fig. 2-A1). ${ }^{63} \mathrm{Ni}$ was mainly associated with the mantle (27 to $44 \%$ ) 253 and the muscle (22 to $32 \%$ ). Distributions were similar for the different exposure treatments, 254 but differed from the distributions observed at the end of the exposure period, with lower 255 fraction associated with digestive gland and higher fractions associated with mantle and 256 muscle. 


\subsection{Food exposure}

258 The loss kinetics of ${ }^{63} \mathrm{Ni}$ ingested with food in both the clam G. tumidum and the oyster $I$. 259 isognomon were best fitted using a double exponential model $\left(\mathrm{R}^{2}=0.49\right.$ and 0.59 , 260 respectively) (Table 3 and Fig. 1-B). A substantial part of the ${ }^{63} \mathrm{Ni}$ activity (39\% for the clam 261 and $83 \%$ for the oyster) was rapidly lost via defecation $\left(\mathrm{T}_{\mathrm{b}^{1 / 2}}<2 \mathrm{~d}\right)$. Assimilation efficiency 262 (AE) of ${ }^{63} \mathrm{Ni}$ was $61 \%$ and $17 \%$ in clams and oysters, respectively. These assimilated 263 fractions were retained with $\mathrm{T}_{\mathrm{b}^{1 / 2}}$ of $35 \mathrm{~d}$ in clams and a time not different from the infinite in 264 oysters. During the depuration period, the highest proportion of ${ }^{63} \mathrm{Ni}(74 \%)$ was associated 265 with visceral mass + mantle in I. isognomon whereas in G. tumidum each organ contributed 266 similarly to the total ${ }^{63} \mathrm{Ni}$ content (Fig. 2-B). In both clam and oyster, ${ }^{63} \mathrm{Ni}$ body distribution 267 showed no major difference between the two sampling times (12 and $46 \mathrm{~d}$ ).

\section{4. Discussion}

Bivalves are well known for their capacity to accumulate metals to quite high levels (e.g. Phillips, 1976). However, few studies have been devoted to Ni in marine bivalves (Friedrich and Fillice, 1976; Hardy and Roesijadi, 1982; Zaroogian and Johnson, 1984; Punt et al.,

272 1998), and particularly in tropical areas.

\subsection{Seawater pathway}

274 Ideally, a bioindicator should bioconcentrate contaminants in direct proportion to the dissolved metal concentration occurring in the environment. This implies that the concentration factor $(\mathrm{CF})$ of a contaminant would remain constant over the concentration range to which the organism could be exposed in its environment (Phillips, 1980, 1990).

278 Previous experimental investigations of Ni bioaccumulation in marine organisms generally 279 considered exposure concentrations (e.g. up to $80 \mathrm{mg} \mathrm{Ni} \mathrm{l}^{-1}$, Friedrich and Fillice, 1976) that were far above (several orders of magnitude) the natural background ones. The concentrations 
tested in the present study (up to $1,400 \mathrm{ng}$ added $\mathrm{Ni}^{-1}$ ) were selected in order to include the 282 entire concentration range which can be measured in the coastal waters of the New 283 Caledonian lagoon (Fernandez et al., 2002). Results showed that the bioconcentration of Ni in 284 the clam $G$. tumidum and in both oysters $M$. regula and I. isognomon was directly 285 proportional to the $\mathrm{Ni}$ concentration in seawater virtually over the entire range of $\mathrm{Ni}$ 286 concentrations tested. Similar observations were made for other elements accumulated by $I$. 287 isognomon and G. tumidum such as $\mathrm{Co}, \mathrm{Cr}, \mathrm{Mn}$ also present in Ni ores (Hédouin, 2006). The capacity of $\mathrm{Ni}$ bioconcentration reported here in clams and oysters $\left(\mathrm{CF}_{14 \mathrm{~d}}\right.$ ranging from 70 to $280 \mathrm{ml} \mathrm{g}^{-1}$ dry wt) was quite lower than that determined in comparable experimental 290 conditions for some metals such as $\mathrm{Ag}$ and $\mathrm{Zn}$, which reached CF values up to $200,000 \mathrm{ml} \mathrm{g}^{-1}$ 291 dry wt (Hédouin, 2006). However, the observed CFs are in the range of those reported in 292 previous studies related to $\mathrm{Ni}$ in bivalves $\left(4 \mathrm{ml} \mathrm{g}^{-1}\right.$ dry wt in the clam Prototheca staminea, 293 Hardy and Roesijadi, 1982; from 10 to $607 \mathrm{ml} \mathrm{g}^{-1}$ dry wt in the mussel Mytilus edulis, 294 Friedrich and Fillice, 1976; from 156 to $336 \mathrm{ml} \mathrm{g}^{-1}$ wet wt in Crassotrea virginica and $M$. 295 edulis, Zaroogian and Johnson, 1984).

296 Results indicated that, in relative units, loss kinetics of Ni from the soft parts of G. tumidum 297 and M. regula were also independent on the Ni concentrations to which the organisms were 298 previously exposed. These observations are in agreement with those of Zaroogian and 299 Johnson, (1984) who reported that the loss rate of Ni was similar in oysters exposed to two 300 different $\mathrm{Ni}$ treatments $\left(5,000\right.$ and $\left.10,000 \mathrm{ng} \mathrm{Ni} \mathrm{l}^{-1}\right)$. In addition, our study showed that $\mathrm{Ni}$ was 301 efficiently retained in both bivalve species, with biological half-lives not significantly 302 different from infinity. These values should of course be considered with caution due to the relatively short duration of the experiment ( $32 \mathrm{~d})$. Nevertheless, they clearly indicate that both 304 clams and oysters would be able to preserve information regarding their contamination history 305 over a very long timescale (probably several months). 
The very close resemblance of the two oyster species $I$. isognomon and $M$. regula, both in their appearance and ecophysiology (Yonge, 1968) was also reflected in their bioaccumulation and depuration capacities for $\mathrm{Co}, \mathrm{Cr}, \mathrm{Zn}$ and, to a lesser extent, $\mathrm{Cd}$ (Hédouin, 2006). Similarly, the present work indicated that bioconcentration of dissolved Ni was quite similar in both species on a whole-body basis, although a slight decrease in CF was observed in I. isognomon at the highest Ni concentration tested. However, examination of CF values at the organ level indicated that gills of I. isognomon concentrate Ni much more efficiently (up to one order of magnitude) than those of $M$. regula. This suggests that although these two species are very closely related in many aspects at a macroscopic scale, mechanisms controlling Ni uptake could be quite different in I. isognomon and M. regula. Furthermore, 316 previous studies have observed that gills are generally a major site of Ni intake in bivalves 317 (e.g. Hardy and Roesijadi, 1982; Wilson, 1983), indicating that this dissimilarity between 318 these two oysters deserves further investigation.

\subsection{Food pathway}

Although it is now well documented that assimilation of metals ingested with food plays an important role in their bioaccumulation in marine organisms (e.g. Wang and Fisher, 1999b), very few studies have been devoted to trophic transfer of Ni. Kumblad et al. (2005) have shown that assimilation efficiency (AE) of sediment-associated ${ }^{63} \mathrm{Ni}$ (II) ranged from 43 to 49 $\%$ in the clam Macoma balthica, the amphipod Monoporeia affinis and the priapulid Halicryptus spinulosus. In the present study, the estimated $\mathrm{AE}$ of ${ }^{63} \mathrm{Ni}$ was much higher in the clam G. tumidum (61\%) than in the oyster I. isognomon (17\%). Such a low assimilation in $I$. 327 isognomon compared to G. tumidum as well as to the species studied by Kumblad et al. 328 (2005) could be related to the differences in feeding physiology (e.g. digestion efficiency) of these different organisms (Lee II, 1991; Mayer et al., 2001). However, in a recent study on 330 other metals, AEs reaching values up to $77 \%$ were found for Ag in I. isognomon (Hédouin, 
2006), suggesting that low AE is not a physiological characteristic of this species. Rather, the

332 low assimilation of $\mathrm{Ni}$ in I. isognomon is likely related to the oyster behaviour towards $\mathrm{Ni}$ and/or how it is able to deal with the way $\mathrm{Ni}$ is bound to algal cells.

334 To the best of our knowledge, the estimated AEs for $\mathrm{Ni}$ are the first published for these 335 species. However, it should be kept in mind that these Ni AEs were obtained in controlled

336 feeding conditions (mono-specific culture of I. galbana at $10^{4}$ cell $\mathrm{ml}^{-1}$ ). These conditions are quite different from those found in the field which are much more complex and variable and which could result in actual AEs somewhat different from those estimated here. It is indeed well known that AE may be influenced by the type of food ingested (Wang and Fisher, 1999a;

340 Chong and Wang, 2000). This has also been recently observed for Co, Mn and $\mathrm{Zn}$ in $G$.

341 tumidum and I. isognomon: AEs estimated for these 3 metals with 3 different species of 342 phytoplankton were found to vary over a factor of 4 (Hédouin, 2006). Hence, Ni AEs estimated in the present study should be considered as preliminary and other feeding

344 conditions should be investigated before making generalisations about $\mathrm{Ni}$ assimilation under 345 environmental conditions.

\subsection{Conclusions}

347 Within a range of dissolved Ni concentrations that cover the natural range occurring in New

348 Caledonia seawaters, (1) $\mathrm{Ni}$ bioconcentration was directly proportional to the $\mathrm{Ni}$

349 concentration in seawater for G. tumidum, M. regula and, to a lesser extent, I. isognomon, and

350 (2) the retention efficiency of $\mathrm{Ni}$ in clams and oysters was independent on the total $\mathrm{Ni}$

351 concentration previously accumulated by the organisms. In addition, clams and oysters were

352 shown to efficiently assimilate Ni ingested with their food (in particular in clams) and retain it 353 very efficiently (in particular in oysters). These characteristics suggest that these New

354 Caledonian bivalves could be used to detect $\mathrm{Ni}$ contamination in their surrounding 355 environment and to preserve this information over long periods of time. In addition, the clams 
356 and oysters displayed different bioaccumulation behaviour for $\mathrm{Ni}$, especially when exposed

357 via the food. Both groups would thus be worth further characterization with regard to their 358 values as bioindicators for $\mathrm{Ni}$ contamination. Indeed, both bivalve groups could provide 359 complementary ecotoxicological information as they interact differently with their 360 environment.

Acknowledgements

The authors are grateful to E. Folcher, C. Peignon and J.L. Menou (IRD-Nouméa

364 Center) for their help in the collection of organisms. $\mathrm{LH}$ is beneficiary of a $\mathrm{PhD}$ grant 365 (CIFRE, France) supported by the Goro-Nickel Company, New Caledonia. MW is an 366 Honorary Senior Research Associate of the National Fund for Scientific Research (NFSR, 367 Belgium). This work was supported by the IAEA, the IRD and the French National PNEC 368 Programme. The IAEA is grateful for the support provided to its Marine Environment 369 Laboratory by the Government of Monaco. 
373 Bird, E.C.F., Dubois, J.P., Iltis, J.A., 1984. The impacts of opencast mining on the rivers and coasts of New Caledonia. The United Nations University, Tokyo, Japan, p. 53.

Bouchet, P., Lozouet, P., Maestrati, P., Heros, V., 2002. Assessing the magnitude of species richness in tropical marine environments: exceptionally high numbers of molluscs at a New Caledonia site Biol J Linn Soc 75, 421-436.

378 Boyden, C.R., 1977. Effect of size upon metal content of shellfish. J Mar Biol Assoc U K 57, 675-714.

Breau, L., 2003. Etude de la bioaccumulation des métaux dans quelques espèces marines tropicales: recherche de bioindicateurs de contamination et application à la surveillance de 382 l'environnement côtier dans le lagon sud-ouest de la Nouvelle-Calédonie. University of La 383 Rochelle La Rochelle, France, p. 282.

Bruland, K.D., 1983. Trace elements in seawater. In: Riley, J.P., Chester, R. (Eds.). Chemical oceanography. Academic Press, London, pp. 157-201.

Chong, K., Wang, W.-X., 2000. Assimilation of cadmium, chromium and zinc by the green mussel Perna viridis and the clam Ruditapes philippinarum. Environ Toxicol Chem 19, 16603881667.

389 Dalvi, A.D., Bacon, W.G., Osborne, R.C., 2004. The past and the future of nickel laterites. 390 PDAC 2004 International Convention, Trade Show \& Investors Exchange, p. 27.

391 Fernandez, J.-M., Breau, L., Cabon, M., Fichez, R., McCorist, G., Magand, O., Moreton, B., 392 Peck, G.A., Szymczak, R., 2002. The fate of metals in New Caledonia. Programme National 393 des Ecosystèmes Côtiers, Banyuls, France.

394 Friedrich, A.R., Fillice, F.P., 1976. Uptake and accumulation of the nickel ion by Mytilus 395 edulis. Bull Environ Contam Toxicol 16, 750-755. 
Goldberg, E.D., Koide, M., Hodge, V., Flegal, A.R., Martin, J.H., 1983. U.S. Mussel Watch: 1977-1978 results on trace metals and radionuclides. Estuar Coast Shelf Sci 16, 69-93.

Hardy, J.T., Roesijadi, G., 1982. Bioaccumulation kinetics and organ distribution of nickel in the marine clam (Protothaca staminea). Bull Environ Contam Toxicol 28, 566-572.

Hédouin, L., 2006. Caractérisation d'espèces bioindicatrices pour la surveillance des activités minières et la gestion de l'environnement en milieu récifal et lagonaire: application au lagon de Nouvelle-Calédonie. Océanologie Biologique et Environnement Marin. University of La Rochelle, La Rochelle, France, p. 328.

Hédouin, L., Metian, M., Teyssié, J.-L., Fowler, S.W., Fichez, R., Warnau, M., 2006. Allometric relationships in the bioconcentration of heavy metals by the edible tropical clam Gafrarium tumidum. Sci Total Environ 366, 154-163.

407 Kumblad, L., Bradshaw, C., Gilek, M., 2005. Bioaccumulation of ${ }^{51} \mathrm{Cr}$, ${ }^{63} \mathrm{Ni}$ and ${ }^{14} \mathrm{C}$ in Baltic 408 Sea benthos. Environ Pollut 134, 45-56.

409 Labrosse, P., Fichez, R., Farman, R., Adams, T., 2000. New Caledonia. In: Sheppard, C.R.C. 410 (Ed.). Seas at the Millenium : An environmental evaluation. Pergamon, Amsterdam, pp. 723411736.

412 Lee II, H., 1991. A clam's eye view of the bioavailability of sediment-associated pollutants. 413 In: Baker, R.A. (Ed.). Organic substances and sediments in water. Lewis Publishers Inc, 414 London pp. 73-93.

415 Mayer, L.M., Weston, D.P., Bock, M.J., 2001. Benzo[a]pyrene and zinc solubilization by 416 digestive fluids of benthic invertebrates - a cross-phyletic study. Environ Toxicol Chem 20, $417 \quad 1890-1900$.

418 Metian, M., 2003. Bioaccumulation des métaux lourds chez 4 espèces marines du lagon de 419 Nouvelle Calédonie: Caractérisation de leur potentiel bioindicateur pour le monitoring des 
activités minières locales. Master Thesis, IAEA-MEL, Monaco / Université Libre de

421 Bruxelles, Belgium, p. 44.

422 Monniot, F., Martoja, R., Monniot, C., 1994. Cellular sites of iron and nickel accumulation in ascidians related to the naturally and anthropic enriched New Caledonian environment. Ann Inst Oceanogr 70, 205-216.

Phillips, D.J.H., 1976. The common mussel Mytilus edulis as an indicator of pollution by zinc, cadmium, lead and copper. II. Relationship of metals in the mussel to those discharged by industry. Mar Biol 38, 71-80.

Phillips, D.J.H., 1980. Quantitative aquatic biological indicators: their use to monitor trace metal and organochlorine pollution. Chapman \& Hall, London.

430 Phillips, D.J.H., 1990. Use of macroalgae and invertebrates as monitors of metal levels in 431 estuaries and coastal waters. In: Furness, R.W., Rainbow, P.S. (Eds.). Heavy metals in the marine environment. CRC Press, Boca Raton, pp. 81-99.

433 Punt, A.G., Millward, G.E., Jones, M.B., 1998. Uptake and depuration of ${ }^{63} \mathrm{Ni}$ by Mytilus 434 edulis. Sci Total Environ 214, 71-78.

435 Thomann, R.V., Mahony, J.D., Mueller, R., 1995. Steady-state model of biota sediment 436 accumulation factor for metals in two marine bivalves. Environ Toxicol Chem 14, 1989-1998. 437 Wang, W.-X., Fisher, N.S., 1999a. Assimilation efficiencies of chemical contaminants in 438 aquatic invertebrates: a synthesis. Environ Toxicol Chem 18, 2034-2045.

439 Wang, W.-X., Fisher, N.S., 1999b. Delineating metal accumulation pathways for marine 440 invertebrates. Sci Total Environ 237/238, 459-472.

441 Warnau, M., Teyssié, J.-L., Fowler, S.W., 1996. Biokinetics of selected heavy metals and 442 radionuclides in the common Mediterranean echinoid Paracentrotus lividus: seawater and 443 food exposure. Mar Ecol Prog Ser 141, 83-94. 
444 Whicker, F.W., Schultz, V., 1982. Radioecology: nuclear energy and the environment. CRC 445 Press, Florida.

446 Wilson, J.G., 1983. The uptake and accumulation of Ni by Cerastoderma edule and its effects

447 on mortality, body condition and respiration rate. Mar Environ Res 8, 129-148.

448 Yonge, C.M., 1968. Form and habit in species of Malleus (including the "hammer oysters")

449 with comparative observations on Isognomon isognomon. Biol Bull 135, 378-405.

450 Zar, J.H., 1996. Biostatistical analysis, Upper Saddle River, New Jersey.

451 Zaroogian, G.E., Johnson, M., 1984. Nickel uptake and loss in the bivalves Crassostrea 452 virginica and Mytilus edulis. Arch Environ Contam Toxicol 13, 411-418.

453

454 
455 Figure 1. Uptake and loss kinetics of ${ }^{63} \mathrm{Ni}$ in whole soft parts of the investigated bivalves.

456 (A) Uptake kinetics (mean concentration factor, $\mathrm{CF} \pm \mathrm{SD}, \mathrm{n}=3$ ) (A-1) and loss kinetics 457 (mean \% remaining activity $\pm \mathrm{SD}, \mathrm{n}=3$ ) (A-2) in the clam Gafrarium tumidum and the oyster 458 Malleus regula exposed to 5 different dissolved Ni concentrations.

459 (B) Loss kinetics (mean \% remaining activity $\pm \mathrm{SD}, \mathrm{n}=14$ ) in the clam G. tumidum and the 460 oyster Isognomon isognomon after a 2-hr feeding on ${ }^{63} \mathrm{Ni}$-labelled Isochrysis galbana.

461

462 Figure 2. Distribution of ${ }^{63} \mathrm{Ni}($ mean \%) among the body compartments of clams and oysters.

463 (A) Body distribution $(\mathrm{n}=5)$ in the seawater experiments in (A-1) the clam Gafrarium 464 tumidum after a 14-d exposure to 5 different dissolved Ni concentrations (end of uptake) and 465 a subsequent 32-d depuration period (end of depuration), and (A-2) the oysters Isognomon 466 isognomon and Malleus regula after a 14-d exposure to the 5 dissolved Ni concentrations.

467 (B) Body distribution $(\mathrm{n}=14)$ in the clam G. tumidum and the oyster I. isognomon, 12 and 46 $468 \mathrm{~d}$ after a 2-hr feeding on ${ }^{3} \mathrm{Ni}-$ labelled Isochrysis galbana cells. 
471 Table 1. Estimated uptake rate constant $\left(\mathrm{k}_{\mathrm{u}}, \mathrm{ml} \mathrm{g}^{-1}\right.$ dry wt $\left.\mathrm{d}^{-1}\right)$, absorption efficiency $\left(\mathrm{A}_{01}, \%\right)$

472 and loss rate constant $\left(\mathrm{k}_{\mathrm{el}}, \mathrm{d}^{-1}\right)$ of ${ }^{63} \mathrm{Ni}$ in the whole soft parts of the clam Gafrarium tumidum 473 and the oyster Malleus regula exposed to five different dissolved $\mathrm{Ni}$ concentrations via 474 seawater for $14 \mathrm{~d}$ (uptake period) and then maintained for $32 \mathrm{~d}$ in the field in a clean site 475 (depuration period).

476 ASE: asymptotic standard error; $\mathrm{R}^{2}$ : determination coefficient of the uptake and loss kinetics

477

478 Table 2. Concentration factors (mean $\mathrm{CF} \pm \mathrm{SD}, \mathrm{ml} \mathrm{g}^{-1}$ dry $\mathrm{wt} ; \mathrm{n}=5$ per species per 479 concentrations tested) of ${ }^{63} \mathrm{Ni}$ in the clam Gafrarium tumidum and the oysters Isognomon 480 isognomon and Malleus regula exposed for $14 \mathrm{~d}$ to 5 different dissolved Ni concentrations $481\left(\mathrm{C}_{0}-\mathrm{C}_{4}\right)$.

482

483 Table 3. Assimilation efficiency (AE, \%), loss rate constant $\left(\mathrm{k}_{\mathrm{el}}, \mathrm{d}^{-1}\right)$ and biological half life $484\left(\mathrm{~T}_{\mathrm{b}^{1 / 2} / 1}, \mathrm{~d}\right)$ of ${ }^{63} \mathrm{Ni}$ in whole soft parts of the clam Gafrarium tumidum and the oyster Isognomon 485 isognomon, after a 2-hr feeding on radiolabelled Isochrysis galbana cells.

486 ASE: asymptotic standard error; $\mathrm{R}^{2}$ : determination coefficient of the loss kinetics 
487 Table 1. Estimated uptake rate constant $\left(\mathrm{k}_{\mathrm{u}}, \mathrm{ml} \mathrm{g}^{-1}\right.$ dry wt $\left.\mathrm{d}^{-1}\right)$, absorption efficiency $\left(\mathrm{A}_{01}, \%\right)$ 488 and loss rate constant $\left(\mathrm{k}_{\mathrm{el}}, \mathrm{d}^{-1}\right)$ of ${ }^{63} \mathrm{Ni}$ in the whole soft parts of the clam Gafrarium tumidum 489 and the oyster Malleus regula exposed to five increasing dissolved Ni concentrations via 490 seawater for $14 \mathrm{~d}$ (uptake period) and then maintained for $32 \mathrm{~d}$ in the field in a clean site 491 (depuration period).

492 ASE: asymptotic standard error; $\mathrm{R}^{2}$ : determination coefficient of the uptake and loss kinetics

\begin{tabular}{c|cc|ccc}
\hline $\begin{array}{c}\text { Concentrations } \\
\text { (ng added Ni 1 }{ }^{-1} \text { ) }\end{array}$ & \multicolumn{2}{|c|}{ Uptake period } & \multicolumn{3}{c}{ Depuration period } \\
$\mathrm{k}_{\mathrm{u}} \pm \mathrm{ASE}$ & $\mathrm{R}^{2}$ & $\mathrm{~A}_{01} \pm \mathrm{ASE}$ & $\mathrm{k}_{\mathrm{el}} \pm \mathrm{ASE}$ & $\mathrm{R}^{2}$ \\
\hline G. tumidum & $9.1 \pm 0.6^{\mathrm{c}}$ & 0.79 & $44 \pm 11^{\mathrm{b}}$ & $0.010 \pm 0.013^{*}$ & 0.72 \\
$\mathrm{C}_{0}: 0$ & $7.2 \pm 0.4^{\mathrm{c}}$ & 0.83 & $27 \pm 20^{*}$ & $0.002 \pm 0.028^{*}$ & 0.84 \\
$\mathrm{C}_{1}: 15$ & $7.7 \pm 0.4^{\mathrm{c}}$ & 0.82 & $45 \pm 18^{\mathrm{a}}$ & $0.002 \pm 0.017^{*}$ & 0.60 \\
$\mathrm{C}_{2}: 75$ & $7.1 \pm 0.4^{\mathrm{c}}$ & 0.82 & $47 \pm 7^{\mathrm{c}}$ & $0.019 \pm 0.009^{*}$ & 0.70 \\
$\mathrm{C}_{3}: 350$ & $5.2 \pm 0.2^{\mathrm{c}}$ & 0.92 & $35 \pm 3^{\mathrm{c}}$ & $0.001 \pm 0.006^{*}$ & 0.77 \\
$\mathrm{C}_{4}: 1400$ & $11.5 \pm 1.0^{\mathrm{c}}$ & 0.72 & $14 \pm 2.3^{\mathrm{c}}$ & & \\
\hline M. regula & $10.1 \pm 0.8^{\mathrm{c}}$ & 0.68 & $7 \pm 3.6^{\mathrm{a}}$ & $\#$ & 0.90 \\
$\mathrm{C}_{0}: 0$ & $14.0 \pm 1.3^{\mathrm{c}}$ & 0.67 & $13 \pm 2.6^{\mathrm{c}}$ & $\#$ & 0.90 \\
$\mathrm{C}_{1}: 15$ & $10.7 \pm 1.0^{\mathrm{c}}$ & 0.63 & $11 \pm 2.1^{\mathrm{c}}$ & $\#$ & 0.94 \\
$\mathrm{C}_{2}: 75$ & $8.1 \pm 0.7^{\mathrm{c}}$ & 0.70 & $9 \pm 5.5^{*}$ & $\#$ & 0.78 \\
$\mathrm{C}_{3}: 350$ & $\mathrm{C}_{4}: 1400$ &
\end{tabular}

493 \# According to the equation fitting the loss kinetics $\left(\mathrm{A}_{\mathrm{t}}=\mathrm{A}_{0 \mathrm{~s}} \mathrm{e}^{-\mathrm{k}_{\mathrm{es}} \mathrm{t}}+\mathrm{A}_{01}\right)$ this parameter $=0$

494 Significance of the estimated parameters: ${ }^{a} \mathrm{p}<0.05,{ }^{\mathrm{b}} \mathrm{p}<0.001,{ }^{\mathrm{c}} \mathrm{p}<0.0001,{ }^{*} \mathrm{p}>0.05$ 495 
496 Table 2. Concentration factors (mean $\mathrm{CF} \pm \mathrm{SD}, \mathrm{ml} \mathrm{g}^{-1}$ dry $\mathrm{wt} ; \mathrm{n}=5$ per species per 497 concentrations tested) of ${ }^{63} \mathrm{Ni}$ in the clam Gafrarium tumidum and the oysters Isognomon 498 isognomon and Malleus regula exposed for $14 \mathrm{~d}$ to 5 increasing dissolved Ni concentrations $499 \quad\left(\mathrm{C}_{0}-\mathrm{C}_{4}\right)$.

\begin{tabular}{|c|c|c|c|c|c|}
\hline Body compartments & $\begin{array}{c}\mathbf{C}_{\mathbf{0}} \\
\text { mean } \pm \mathrm{SD}\end{array}$ & $\begin{array}{c}\mathbf{C}_{\mathbf{1}} \\
\text { mean } \pm \mathrm{SD}\end{array}$ & $\begin{array}{c}\mathbf{C}_{2} \\
\text { mean } \pm \mathrm{SD}\end{array}$ & $\begin{array}{c}\mathbf{C}_{\mathbf{3}} \\
\text { mean } \pm \mathrm{SD}\end{array}$ & $\begin{array}{c}\mathbf{C}_{\mathbf{4}} \\
\text { mean } \pm \mathrm{SD}\end{array}$ \\
\hline \multicolumn{6}{|l|}{ G. tumidum } \\
\hline Shell & $2.0 \pm 0.4$ & $2.0 \pm 0.3$ & $2.2 \pm 0.1$ & $2.0 \pm 0.2$ & $1.6 \pm 0.3$ \\
\hline Whole soft parts & $129 \pm 61$ & $94 \pm 19$ & $87 \pm 7.3$ & $90 \pm 25$ & $70 \pm 11$ \\
\hline Digestive gland & $620 \pm 200$ & $306 \pm 126$ & $286 \pm 31$ & $356 \pm 43$ & $235 \pm 129$ \\
\hline Gills & $206 \pm 11$ & $151 \pm 43$ & $176 \pm 41$ & $164 \pm 12$ & $112 \pm 24$ \\
\hline Mantle & $114 \pm 52$ & $69 \pm 13$ & $62 \pm 9.4$ & $75 \pm 47$ & $58 \pm 7.1$ \\
\hline Muscle & $52 \pm 18$ & $36 \pm 3.2$ & $32 \pm 8.8$ & $42 \pm 33$ & $32 \pm 3.1$ \\
\hline Foot & $17 \pm 11$ & $27 \pm 6.4$ & $29 \pm 13$ & $18 \pm 4.2$ & $16 \pm 2.1$ \\
\hline Remaining tissues & $123 \pm 50$ & $96 \pm 34$ & $62 \pm 11$ & $93 \pm 48$ & $64 \pm 20$ \\
\hline \multicolumn{6}{|l|}{ I. isognomon } \\
\hline Shell & $1.4 \pm 0.1$ & $1.6 \pm 0.4$ & $1.2 \pm 0.4$ & $1.2 \pm 0.2$ & $0.9 \pm 0.1$ \\
\hline Whole soft parts & $213 \pm 70$ & $262 \pm 20$ & $284 \pm 105$ & $171 \pm 61$ & $143 \pm 52$ \\
\hline Visceral mass + Mantle & $232 \pm 74$ & $295 \pm 35$ & $305 \pm 116$ & $175 \pm 71$ & $155 \pm 70$ \\
\hline Gills & $456 \pm 177$ & $519 \pm 93$ & $660 \pm 265$ & $460 \pm 148$ & $338 \pm 91$ \\
\hline Muscle & $110 \pm 8.3$ & $77 \pm 30$ & $85 \pm 34$ & $113 \pm 19$ & $75 \pm 47$ \\
\hline \multicolumn{6}{|l|}{ M. regula } \\
\hline Shell & $42 \pm 29$ & $47 \pm 35$ & $53 \pm 36$ & $60 \pm 48$ & $67 \pm 24$ \\
\hline Whole soft parts & $183 \pm 76$ & $133 \pm 53$ & $205 \pm 107$ & $136 \pm 19$ & $106 \pm 24$ \\
\hline Visceral mass + Mantle & $249 \pm 98$ & $1901 \pm 93$ & $265 \pm 161$ & $186 \pm 12$ & $178 \pm 43$ \\
\hline Gills & $176 \pm 134$ & $77 \pm 15$ & $94 \pm 12$ & $79 \pm 13$ & $38 \pm 15$ \\
\hline Muscle & $69 \pm 63$ & $54 \pm 23$ & $101 \pm 61$ & $67 \pm 48$ & $43 \pm 28$ \\
\hline
\end{tabular}


Table 3. Assimilation efficiency (AE, \%), loss rate constant $\left(\mathrm{k}_{\mathrm{e}}, \mathrm{d}^{-1}\right)$ and biological half life $\left(\mathrm{T}_{\mathrm{b}^{1 / 2}, \mathrm{~d}}\right)$ of ${ }^{63} \mathrm{Ni}$ in whole soft parts of the clam Gafrarium tumidum and the oyster Isognomon isognomon, after a 2-hr feeding on radiolabelled Isochrysis galbana cells.

ASE: asymptotic standard error; $\mathrm{R}^{2}$ : determination coefficient of the loss kinetics

\begin{tabular}{ccccc}
\hline Species & $\mathbf{A E} \pm \mathbf{A S E}$ & $\mathbf{k}_{\mathbf{e}} \pm \mathbf{A S E}$ & $\mathbf{T}_{\mathbf{b} 1 / 2} \pm \mathbf{S D}$ & $\mathbf{R}^{\mathbf{2}}$ \\
\hline G. tumidum & $61.2 \pm 4.5^{\mathrm{b}}$ & $0.019 \pm 0.04^{\mathrm{b}}$ & $35 \pm 7$ & 0.49 \\
\hline I. isognomon & $17.1 \pm 6.9^{\mathrm{a}}$ & $0.0001 \pm 0.015^{*}$ & n.s.i. & 0.59 \\
\hline
\end{tabular}

Significance of the estimated parameters ${ }^{\mathrm{a}} \mathrm{p}<0.05,{ }^{\mathrm{b}} \mathrm{p}<0.0001,{ }^{*} \mathrm{p}>0.05$

n.s.i.: $\mathrm{T}_{\mathrm{b} / 2}$ not significantly different from infinite 
Figure 1. Uptake and loss kinetics of ${ }^{63} \mathrm{Ni}$ in whole soft parts of the investigated bivalves.

(A) Uptake kinetics (mean concentration factor, $\mathrm{CF} \pm \mathrm{SD}, \mathrm{n}=3$ ) (A-1) and loss kinetics (mean \% remaining activity $\pm \mathrm{SD}, \mathrm{n}=3)(\mathrm{A}-2)$ in the clam Gafrarium tumidum and the oyster Malleus regula exposed to 5 increasing dissolved Ni concentrations.

(B) Loss kinetics (mean \% remaining activity $\pm \mathrm{SD}, \mathrm{n}=14$ ) in the clam G. tumidum and the oyster Isognomon isognomon after a 2-hr feeding on ${ }^{63} \mathrm{Ni}$-labelled Isochrysis galbana.

\section{A- SEAWATER}

\section{A-1. UPTAKE}
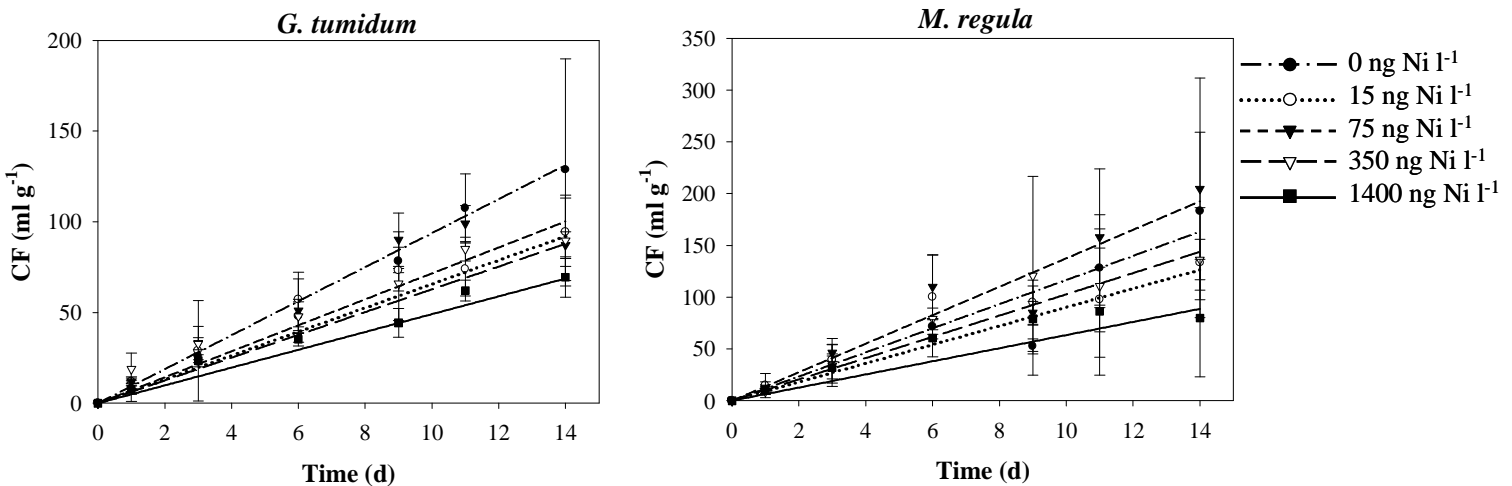

A-2. LOSS
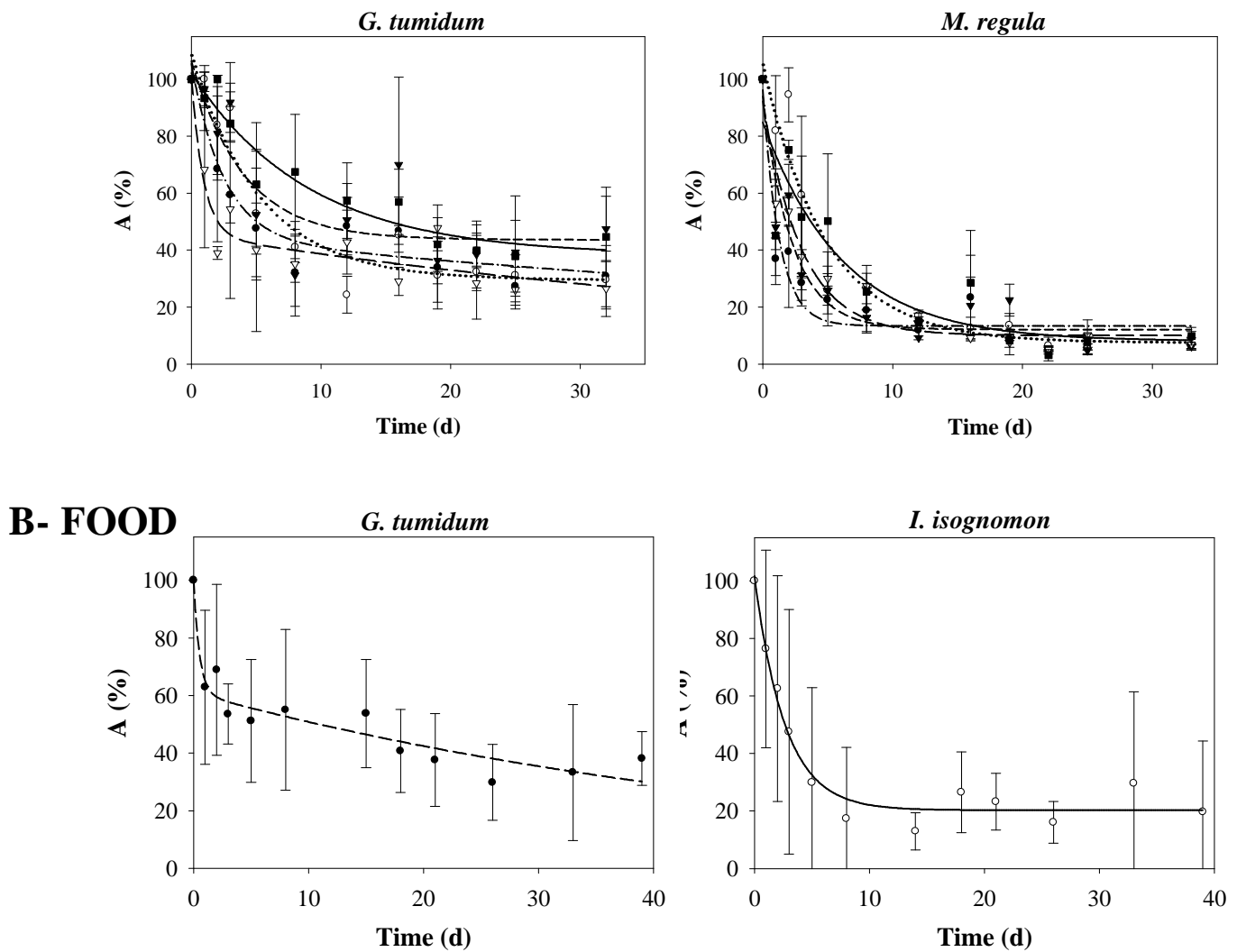
Figure 2. Distribution of ${ }^{63} \mathrm{Ni}($ mean $\%$ ) among the body compartments of clams and oysters.

(A) Body distribution $(\mathrm{n}=5)$ in the seawater experiments in (A-1) the clam Gafrarium tumidum after a 14-d exposure to 5 increasing dissolved Ni concentrations (end of uptake) and a subsequent 32-d depuration period (end of depuration), and (A-2) the oysters Isognomon isognomon and Malleus regula after a 14-d exposure to the 5 dissolved Ni concentrations.

(B) Body distribution $(\mathrm{n}=14)$ in the clam G. tumidum and the oyster I. isognomon, 12 and 46 d after a 2-hr feeding on ${ }^{3} \mathrm{Ni}$-labelled Isochrysis galbana cells.

\section{A- SEAWATER}

\section{A-1. Clams}
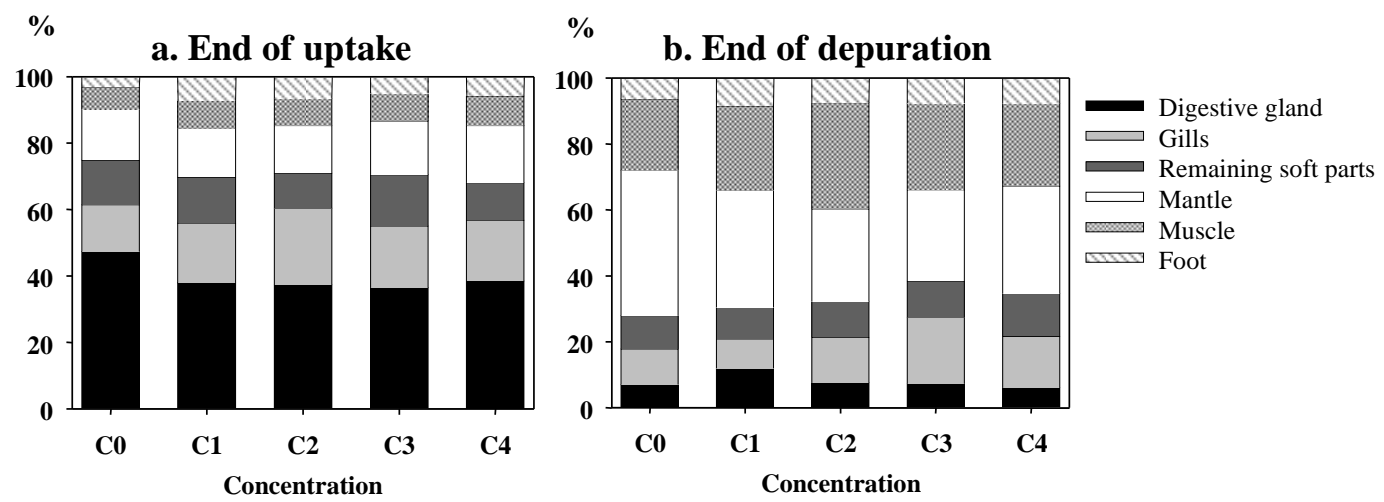

\section{A-2. Oysters}
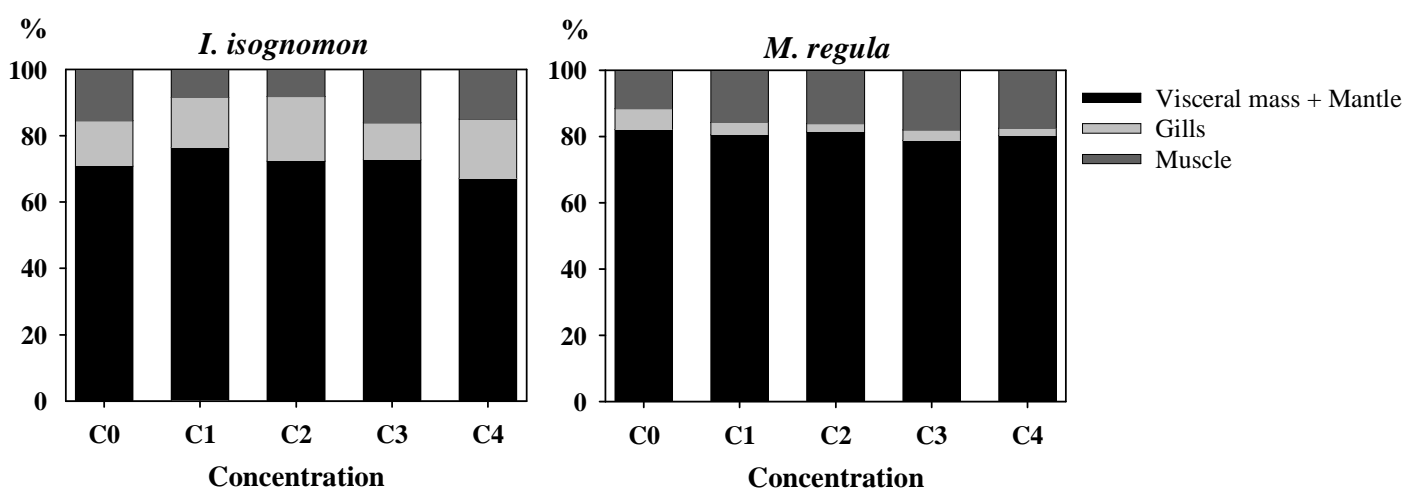

\section{B- FOOD}
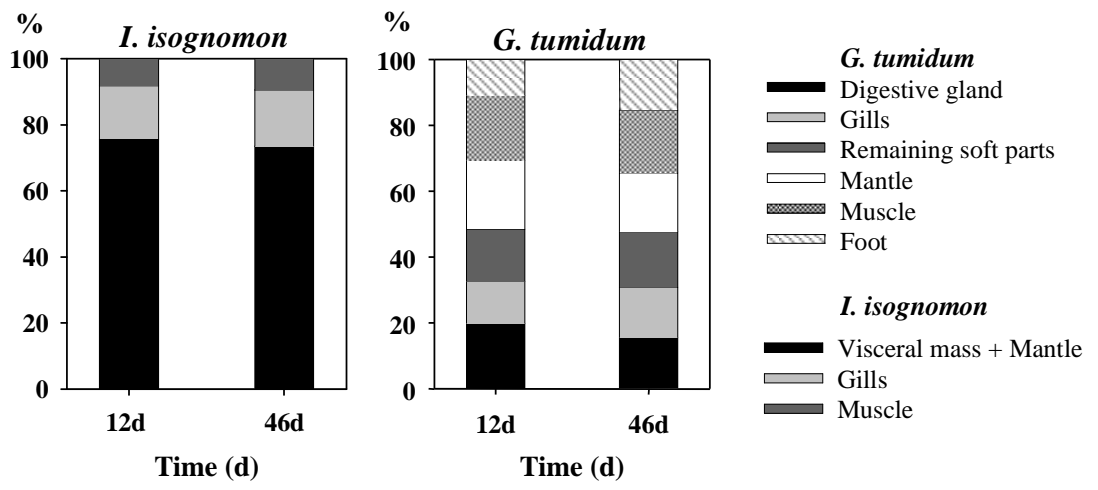